\title{
Gender Does Not Have a Potential Predictive Value for the Presence of Epidermal Growth Factor Receptor Mutation in Lung Adenocarcinoma
}

\author{
Masaki Tomita, Takanori Ayabe, Eiichi Chosa, Katsuya Kawagoe, Kunihide Nakamura \\ Department of Surgery II, Faculty of Medicine, University of Miyazaki, Miyazaki, Japan \\ Email: mtomita@med.miyazaki-u.ac.jp
}

Received 20 October 2014; revised 25 November 2014; accepted 8 December 2014

Academic Editor: Ram Prasad, University of Alabama, USA

Copyright (C) 2014 by authors and Scientific Research Publishing Inc.

This work is licensed under the Creative Commons Attribution International License (CC BY).

http://creativecommons.org/licenses/by/4.0/

(c) (i) Open Access

\section{Abstract}

Background: Previous studies reported that non-small cell carcinoma patients characterized by female gender, never-smoking status and adenocarcinoma histology were more likely to harbor epidermal growth factor receptor (EGFR) mutations. However, some studies failed to find the relationship between EGFR mutation and gender. Methods: One hundred and eighty-four consecutive patients (90 men and 94 women) of resected lung adenocarcinoma were studied retrospectively. Since the smoking rate is significantly higher in men, we assumed that gender difference might be a seeming factor affected by smoking. Therefore we subdivided the patients into 2 groups: neverand ever-smokers. Results: The number of ever-smokers was $94.44 \%$ in men, whereas $8.51 \%$ in women. EGFR mutation was positive in $48.9 \%$. For overall patients, EGFR mutation status was associated with gender, pStage, pT status, lepidic dominant histologic subtype, pure/mixed groundglass opacity (GGO) on computed tomography (CT) and smoking status. However, in ever-smokers, EGFR mutation status was associated with lepidic histologic subtype and GGO on CT, but not others including gender. Similar results were also found in never-smokers, and gender was not also related to EGFR mutation in never smokers. Conclusion: The EGFR mutational frequency among men and women was not significantly different when lung adenocarcinoma patients were stratified into never- and ever-smokers.

\section{Keywords}

Epidermal Growth Factor Receptor Mutation, Smoker, Gender, Non-Small Cell Lung Cancer, Adenocarcinoma, Brinkman Index 


\section{Introduction}

Epidermal growth factor receptor (EGFR), a transmembrane glycoprotein, is involved in the cancer cell proliferation, angiogenesis, and resistance to apoptosis [1] [2]. EGFR kinase domain mutations (i.e., deletions in exon 19 and L858R point mutations in exon 21) were found to be highly associated with increased sensitivity to EGFR tyrosine kinase inhibitors [3].

Previous studies have revealed that EGFR mutation was higher in the never-smoker Asian females with lung adenocarcinoma [4]-[6]. On the other hand, some studies failed to find the relationship between EGFR mutation and gender [7]-[9]. The majority of women with NSCLC, particularly in Asian populations, have no or slight history of smoking. Therefore, gender difference might be a seeming factor affected by smoking. In other words, there is a possibility that the EGFR mutational frequency among men and women was not significantly different when lung adenocarcinoma patients were stratified into never- and ever-smokers. In the present study, therefore, we subdivided the lung adenocarcinoma patients into 2 groups: never- and ever-smokers, and examined the clinical factors that related to EGFR mutation.

\section{Patients and Methods}

One hundred and eighty-four consecutive patients (90 men and 94 women) of resected lung adenocarcinoma who underwent surgery from 2007 to 2012 in our hospital and for whom EGFR mutation status were available were enrolled into the present retrospective study. Patients were subdivided the patients into 2 groups: neverand ever-smokers.

The preoperative serum CEA level was measured using the two-site immunoenzymometric assay; the normal upper limit for this assay was $5.0 \mathrm{ng} / \mathrm{mL}$. Surgical samples were analyzed for EGFR mutation using Cycleave polymerase chain reaction (PCR) method by SRL Inc. (Tokyo, Japan) [10]. The lifetime consumption of cigarette smoke was assessed using the Brinkman index, calculated by the numbers of cigarettes smoked per day multiplied by the smoking years [11]. Pathological (p) tumor-node-metastasis (TNM) staging was recorded in all patients based on the 7th edition of the American Joint Committee on Cancer (AJCC)/Union for International Cancer Control (UICC) classification. Histologic subtype was also recorded based on International association for the study of lung cancer/American thoracic society/European respiratory society international multidisciplinary classification of lung adenocarcinoma [12].

Follow-up information, including cause of death, was ascertained through a review of clinic notes and direct or family contact. The chi-square test with Yates' correction was applied to test any association between the clinical characteristics and EGFR mutation status. Paired $t$-test was applied to assess any significant differences in the Brinkman index. Statistical calculations were conducted with JMP (SAS Institute Inc., Cary, NC, USA) and values of $p$ less than 0.05 were accepted as being significant.

\section{Results}

The number of current or former smokers was 85/90 (94.44\%) in men, whereas that was 8/94 (8.51\%) in women. There was a significant difference in smoking status between men and women $(p<0.001)$.

EGFR mutation was positive in $48.9 \%$ and negative (wild type) in 51.1\%. The clinical factors that related to EGFR mutation in all patients were shown in Table 1. Overall mutation was significant in women (65.96\% vs. $32.22 \%)$ compared with men $(p<0.001)$. Similarly EGFR mutation positive ratio was $67.03 \%$ in never-smokers, whereas $32.25 \%$ in ever-smokers $(p<0.001)$. Based on the previous study by Lee et al. [10], the histologic subtype was subdivided into 2 groups: lepidic dominant histologic subtype, including adenocarcinoma in situ, minimally invasive adenocarcinoma, and lepidic predominant invasive adenocarcinoma versus other subtypes. The pStage, pT status, lepidic dominant histologic subtype and pure/mixed ground-glass opacity (GGO) on computed tomography (CT) were also significantly associated with the presence of the EGFR mutation for overall patients in addition to gender and smoking status (Table 1).

On the other hand, in never-smokers, EGFR mutation status was associated with pStage, lepidic dominant histologic subtype and pure/mixed GGO on CT, while age, gender, pT status, pN status and serum CEA level were not (Table 2). The relationship between EGFR mutation status and clinical characteristics in ever-smoker was also shown in Table 3. Similarly, in ever-smokers, EGFR mutation status was associated with lepidic dominant histologic subtype and pure/mixed GGO but not others including gender. Since, Brinkman index group was not related to EGFR mutation in ever-smokers (Table 3), we also compared the Brinkman index based on 
Table 1. Comparison of clinical characteristics of all patients based on EGFR mutation status.

\begin{tabular}{|c|c|c|c|c|}
\hline & & Wild type & Mutant EGFR & $p$ value \\
\hline \multirow[t]{2}{*}{ Age } & $<65$ & 58 & 57 & 0.970 \\
\hline & $\geq 65$ & 35 & 34 & \\
\hline \multirow[t]{2}{*}{ Gender } & Men & 61 & 29 & $<0.0001$ \\
\hline & Women & 32 & 62 & \\
\hline \multirow[t]{2}{*}{ pStage } & I & 58 & 74 & 0.004 \\
\hline & II - IV & 35 & 17 & \\
\hline \multirow[t]{2}{*}{ pT status } & pT1 & 52 & 69 & 0.0042 \\
\hline & pT2 - 3 & 41 & 22 & \\
\hline \multirow[t]{2}{*}{ pN status } & pNO & 70 & 76 & 0.1657 \\
\hline & pN1 - 2 & 23 & 15 & \\
\hline \multirow[t]{2}{*}{ Histology } & Lepidic dominant & 15 & 40 & 0.0001 \\
\hline & Others & 78 & 51 & \\
\hline \multirow[t]{2}{*}{ CT findings } & Pure/mixed GGO & 19 & 49 & $<0.0001$ \\
\hline & Solid & 74 & 42 & \\
\hline \multirow[t]{2}{*}{ Smoking status } & Never & 30 & 61 & $<0.0001$ \\
\hline & Ever & 63 & 30 & \\
\hline \multirow[t]{2}{*}{ CEA } & Normal & 60 & 66 & 0.2416 \\
\hline & High & 33 & 25 & \\
\hline
\end{tabular}

GGO: ground-glass opacity; CEA: carcinoembryonic antigen.

Table 2. Comparison of clinical characteristics of never-smokers based on EGFR mutation status.

\begin{tabular}{|c|c|c|c|c|}
\hline & & Wild type & Mutant EGFR & $p$ value \\
\hline \multirow[t]{2}{*}{ Age } & $<65$ & 10 & 19 & 0.8334 \\
\hline & $\geq 65$ & 20 & 42 & \\
\hline \multirow[t]{2}{*}{ Sex } & Male & 2 & 3 & 0.7308 \\
\hline & Female & 28 & 58 & \\
\hline \multirow[t]{2}{*}{ pStage } & I & 19 & 52 & 0.0176 \\
\hline & II - III & 11 & 9 & \\
\hline \multirow[t]{2}{*}{ pT sttatus } & pT1 & 20 & 46 & 0.3797 \\
\hline & pN1 - 2 & 10 & 15 & \\
\hline \multirow[t]{2}{*}{ pN status } & pNO & 22 & 52 & 0.1705 \\
\hline & pN1 - 2 & 8 & 9 & \\
\hline \multirow[t]{2}{*}{ CEA } & Normal & 24 & 47 & 0.7493 \\
\hline & High & 6 & 14 & \\
\hline \multirow[t]{2}{*}{ Histology } & Lepidic dominant & 8 & 30 & 0.0406 \\
\hline & Others & 22 & 31 & \\
\hline \multirow[t]{2}{*}{ CT findings } & Pure/mixed GGO & 11 & 39 & 0.014 \\
\hline & Solid & 19 & 22 & \\
\hline
\end{tabular}

GGO: ground-glass opacity; CEA: carcinoembryonic antigen. 
Table 3. Comparison of clinical characteristics of ever-smokers based on EGFR mutation status.

\begin{tabular}{|c|c|c|c|c|}
\hline & & Wild type & Mutant EGFR & $p$ value \\
\hline \multirow[t]{2}{*}{ Age } & $<65$ & 25 & 15 & 0.3475 \\
\hline & $\geq 65$ & 38 & 15 & \\
\hline \multirow[t]{2}{*}{ Sex } & Male & 59 & 26 & 0.2615 \\
\hline & Female & 4 & 4 & \\
\hline \multirow[t]{2}{*}{ pStage } & I & 39 & 22 & 0.2781 \\
\hline & II - III & 24 & 8 & \\
\hline \multirow[t]{2}{*}{ pT status } & pT1 & 32 & 23 & 0.0177 \\
\hline & pN1 - 2 & 31 & 7 & \\
\hline \multirow[t]{2}{*}{$\mathrm{pN}$ status } & pNO & 48 & 24 & 0.6813 \\
\hline & pN1 - 2 & 15 & 6 & \\
\hline \multirow[t]{3}{*}{ Brinkman index } & $<500$ & 19 & 14 & 0.2782 \\
\hline & $500-1000$ & 25 & 10 & \\
\hline & $>1000$ & 19 & 6 & \\
\hline \multirow[t]{2}{*}{ CEA } & Normal & 36 & 19 & 0.5702 \\
\hline & High & 27 & 11 & \\
\hline \multirow[t]{2}{*}{ Histology } & Lepidic dominant & 7 & 10 & 0.0095 \\
\hline & Others & 56 & 20 & \\
\hline \multirow[t]{2}{*}{ CT findings } & Pure/mixed GGO & 8 & 10 & 0.0185 \\
\hline & Solid & 55 & 20 & \\
\hline
\end{tabular}

GGO: ground-glass opacity; CEA: carcinoembryonic antigen.

the EGFR mutation status. The Brinkman index of patients with wild type was $836.2 \pm 527.1$, whereas that with mutant EGFR was 706.3 \pm 581.7 . No significant difference was found in these 2 groups $(p=0.848)$.

\section{Discussion}

A high prevalence of EGFR mutations in our study population was found in our series (48.9\%), which was consistent with several other studies showing high incidence of EGFR mutation in Asian patients [4]-[6].

The EGFR mutational frequency among never- and ever-smokers was significantly different. Although the mechanism of EGFR mutation has not yet been elucidated in detail, never-smoking status might play a key role for EGFR mutation. On the other hand, 32.25\% of smokers had EGFR mutations, therefore there might be other EGFR mutational mechanisms which are not related to smoking.

Is has been well accepted that never-smoking status, women, adenocarcinoma and Asians ethnicity have been considered the most important factors associated with EGFR mutations in non-small cell lung cancer (NSCLC) [4]-[6]. In addition, previous studies reported that pure/mixed GGO and lepidic dominant histologic subtype could be better predictors for EGFR mutation in lung adenocarcinoma [13]-[15]. In our results, both lepidic dominant histologic subtype and pure/mixed GGO were related to EGFR mutation in never-smokers, as well as ever-smokers. It has been reported the association between lepidic histologic subtype and GGO [16]. Therefore we believe that the EGFR mutational mechanisms of patients with lepidic dominant histologic subtype and GGO are similar, and these mechanisms might be common in never- and ever-smokers.

Overall mutation rate was significant in women compared with men. This result was consistent with several other studies [4]-[6]. However some studies showed that EGFR mutation was not associated with gender [7]-[9]. The well-known difference between men and women was smoking habits. The majority of women with NSCLC, particularly in Asian populations, have no or slight history of smoking. In our results, the majority of women (86/94) are also never-smokers. Since the smoking rate is several-fold different between men and women, the 
variables affected by smoking may show a seeming gender difference. Thus, to eliminate the effect of such confounding variables, we stratified our patients into never- and ever-smokers. In never-smokers, women have $67 \%$ (58/86) EGFR mutation as compared with men (60\% (3/5)). In ever-smokers, 50\% (4/8) females have EGFR mutation, while only $30 \%(26 / 85)$ male patients have EGFR mutation. There was a trend towards an association between EGFR mutation and female gender but this did not reach statistical significance. In our results, therefore, gender, which has often been used as a criterion for selecting a patient group populated with EGFR mutations in clinical medicine, was not significantly associated. Thus we believe that the difference in EGFR mutation ratio among men and women might be due to smoking but not gender itself. It can be considered that gender does not have a potential predictive value for the presence of EGFR mutations in lung adenocarcinoma. Hsiao et al. [8] concluded that gender is a confounding factor for EGFR mutations in NSCLC.

It is infallible that smoking is a pivotal factor for EGFR mutation. D'Angelo et al. [7] also showed an inverse relationship between the incidence of EGFR mutations and the number of pack-years of cigarette smoking, with fewer mutations found in patients with greater smoking. However we failed to find the relationship between EGFR mutation and Brinkman index in smokers. The reason for this discrepancy is unknown. Possible variables among these studies were use of different population of the studied patients. Further studies whether the amount or duration of smoking is related to EGFR mutation or not are required.

\section{Conclusion}

In conclusions, the EGFR mutational frequency among men and women was not significantly different when lung adenocarcinoma patients were stratified into never- and ever-smokers. The gender difference might be a seeming factor affected by smoking. Therefore we believe that all patients with lung adenocarcinoma should undergo EGFR mutation testing, regardless of clinical characteristics.

\section{References}

[1] Olayioye, M.A., Neve, R.M., Lane, H.A. and Hynes, N.E. (2000) The ErbB Signaling Network: Receptor Heterodimerization in Development and Cancer. The EMBO Journal, 19, 3159-3167. http://dx.doi.org/10.1093/emboj/19.13.3159

[2] Pinkas-Kramarski, R., Soussan, L., Waterman, H., Levkowitz, G., Alroy, I., Klapper, L., Lavi, S., Seger, R., Ratzkin, B.J., Sela, M. and Yarden, Y. (1996) Diversification of Neu Differentiation Factor and Epidermal Growth Factor Signaling by Combinatorial Receptor Interactions. The EMBO Journal, 15, 2452-2467.

[3] Lynch, T.J., Bell, D.W., Sordella, R., Gurubhagavatula, S., Okimoto, R.A., Brannigan, B.W., Harris, P.L., Haserlat, S.M., Supko, J.G., Haluska, F.G., Louis, D.N., Christiani, D.C., Settleman, J. and Haber, D.A. (2004) Activating Mutations in the Epidermal Growth Factor Receptor Underlying Responsiveness of Non-Small-Cell Lung Cancer to Gefitinib. The New England Journal of Medicine, 350, 2129-2139. http://dx.doi.org/10.1056/NEJMoa040938

[4] Kosaka, T., Yatabe, Y., Endoh, H., Kuwano, H., Takahashi, T. and Mitsudomi, T. (2004) Mutations of the Epidermal growth Factor Receptor Gene in Lung Cancer: Biological and Clinical Implications. Cancer Research, 64, 8919-8923. http://dx.doi.org/10.1158/0008-5472.CAN-04-2818

[5] Shigematsu, H., Lin, L., Takahashi, T., Nomura, M., Suzuki, M., Wistuba, I.I., Fong, K.M., Lee, H., Toyooka, S., Shimizu, N., Fujisawa, T., Feng, Z., Roth, J.A., Herz, J., Minna, J.D. and Gazdar, A.F. (2005) Clinical and Biological Features Associated with Epidermal Growth Factor Receptor Gene Mutations in Lung Cancers. Journal of the National Cancer Institute, 97, 339-346. http://dx.doi.org/10.1093/jnci/dji055

[6] Mitsudomi, T., Kosaka, T. and Yatabe, Y. (2006) Biological and Clinical Implications of EGFR Mutations in Lung Cancer. International Journal of Clinical Oncology, 11, 190-198. http://dx.doi.org/10.1007/s10147-006-0583-4

[7] D’Angelo, S.P., Pietanza, M.C., Johnson, M.L., Riely, G.J., Miller, V.A., Sima, C.S., Zakowski, M.F., Rusch, V.W., Ladanyi, M. and Kris, M.G. (2011) Incidence of EGFR Exon 19 Deletions and L858R in Tumor Specimens from Men and Cigarette Smokers with Lung Adenocarcinomas. Journal of Clinical Oncology, 29, 2066-2070. http://dx.doi.org/10.1200/JCO.2010.32.6181

[8] Hsiao, S.H., Lin, S.E., Chou, Y.T., Wang, J.L., Chung, C.L., Yu, M.C., Fang, C.L., Lee, H.L., Chiang, L.L., Liu, H.E. and Wu, C.W. (2014) Histological Subtype and Smoking Status, But Not Gender, Are Associated with Mutations in Non-Small-Cell Lung Cancer. Molecular and Clinical Oncology, 2, 252-258.

[9] Tanaka, T., Matsuoka, M., Sutani, A., Gemma, A., Maemondo, M., Inoue, A., Okinaga, S., Nagashima, M., Oizumi, S., Uematsu, K., Nagai, Y., Moriyama, G., Miyazawa, H., Ikebuchi, K., Morita, S., Kobayashi, K. and Hagiwara, K. (2010) Frequency of and Variables Associated with the EGFR Mutation and Its Subtypes. International Journal of Cancer, 126, 651-655. http://dx.doi.org/10.1002/ijc.24746 
[10] Yatabe, Y., Hida, T., Horio, Y., Kosaka, T., Takahashi, T. and Mitsudomi, T. (2006) A Rapid, Sensitive Assay to Detect EGFR Mutation in Small Biopsy Specimens from Lung Cancer. The Journal of Molecular Diagnostics, 8, 335-341. http://dx.doi.org/10.2353/jmoldx.2006.050104

[11] Brinkman, G.L. and Coates Jr., E.O. (1963) The Effect of Bronchitis, Smoking, and Occupation on Ventilation. The American Review of Respiratory Disease, 87, 684-693.

[12] Travis, W.D., Brambilla, E., Noguchi, M., Nicholson, A.G., Geisinger, K.R., Yatabe, Y., Beer, D.G., Powell, C.A., Riely, G.J., Van Schil, P.E., Garg, K., Austin, J.H., Asamura, H., Rusch, V.W., Hirsch, F.R., Scagliotti, G., Mitsudomi, T., Huber, R.M., Ishikawa, Y., Jett, J., Sanchez-Cespedes, M., Sculier, J.P., Takahashi, T., Tsuboi, M., Vansteenkiste, J., Wistuba, I., Yang, P.C., Aberle, D., Brambilla, C., Flieder, D., Franklin, W., Gazdar, A., Gould, M., Hasleton, P., Henderson, D., Johnson, B., Johnson, D., Kerr, K., Kuriyama, K., Lee, J.S., Miller, V.A., Petersen, I., Roggli, V., Rosell, R., Saijo, N., Thunnissen, E., Tsao, M. and Yankelewitz, D. (2011) International Association for the Study of Lung Cancer/American Thoracic Society/European Respiratory Society International Multidisciplinary Classification of Lung Adenocarcinoma. Journal of Thoracic Oncology, 6, 244-285. http://dx.doi.org/10.1097/JTO.0b013e318206a221

[13] Lee, H.J., Kim, Y.T., Kang, C.H., Zhao, B., Tan, Y., Schwartz, L.H., Persigehl, T., Jeon, Y.K. and Chung, D.H. (2013) Epidermal Growth Factor Receptor Mutation in Lung Adenocarcinomas: Relationship with CT Characteristics and Histologic Subtypes. Radiology, 268, 254-264. http://dx.doi.org/10.1148/radiol.13112553

[14] Hsieh, R.K., Lim, K.H., Kuo, H.T., Tzen, C.Y. and Huang, M.J. (2005) Female Sex and Bronchioloalveolar Pathologic Subtype Predict EGFR Mutations in Non-Small Cell Lung Cancer. Chest, 128, 317-321. http://dx.doi.org/10.1378/chest.128.1.317

[15] Yano, M., Sasaki, H., Kobayashi, Y., Yukiue, H., Haneda, H., Suzuki, E., Endo, K., Kawano, O., Hara, M. and Fujii, Y. (2006) Epidermal Growth Factor Receptor Gene Mutation and Computed Tomographic Findings in Peripheral Pulmonary Adenocarcinoma. Journal of Thoracic Oncology, 1, 413-416. http://dx.doi.org/10.1097/01243894-200606000-00006

[16] Ambrosini-Spaltro, A., Ruiu, A., Seebacher, C., Vattemi, E., Gentile, L., Feil, B., Zaraca, F. and Carella, R. (2014) Impact of the IASLC/ATS/ERS Classification in pN0 Pulmonary Adenocarcinomas: A Study with Radiological-Pathological Comparisons and Survival Analyses. Pathology, Research and Practice, 210, 40-46. http://dx.doi.org/10.1016/j.prp.2013.09.016 
Scientific Research Publishing (SCIRP) is one of the largest Open Access journal publishers. It is currently publishing more than 200 open access, online, peer-reviewed journals covering a wide range of academic disciplines. SCIRP serves the worldwide academic communities and contributes to the progress and application of science with its publication.

Other selected journals from SCIRP are listed as below. Submit your manuscript to us via either submit@scirp.org or Online Submission Portal.
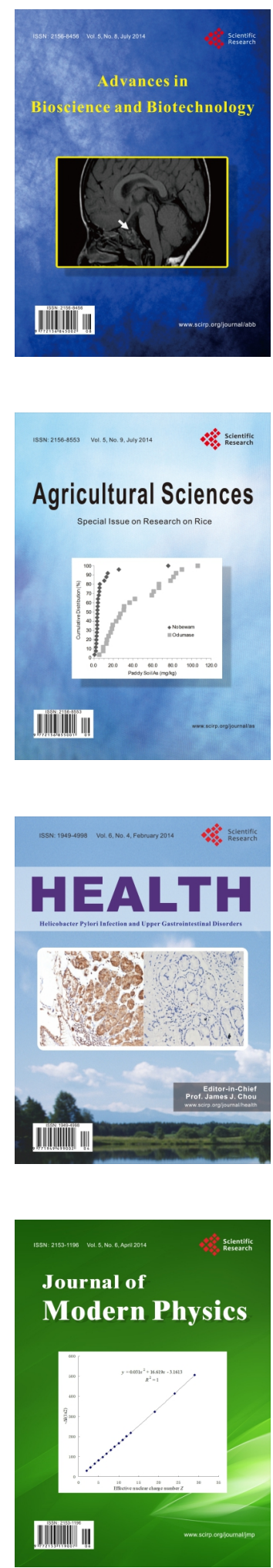
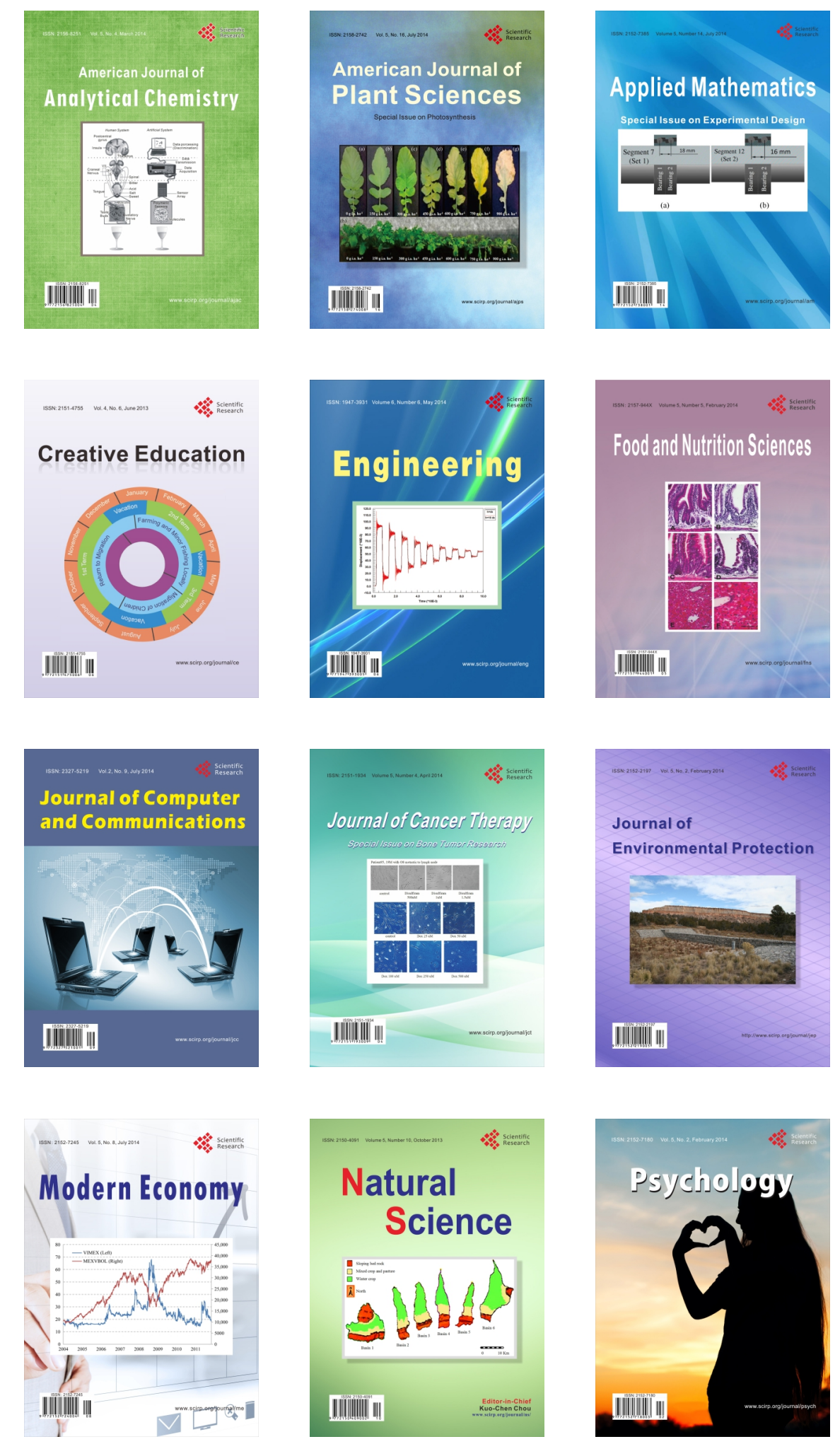